\title{
AKTIVITAS ANTIOKSIDAN EKSTRAK METANOL DARI DAUN SOYOGIK (Saurauia Bracteosa DC.)
}

\author{
Marfel G. D. Muaja ${ }^{1)}$, Max R. J. Runtuwene ${ }^{1)}$, Vanda S. Kamu ${ }^{1)}$ \\ Program Studi Kimia, Fakultas Matematika dan Ilmu Pengetahuan Alam, \\ Universitas Sam Ratulangi, Manado \\ muajaglen@gmail.com,max_runtuwene@yahoo.com,vandakamu05@gmail.com
}

\begin{abstract}
ABSTRAK
Penelitian ini bertujuan untuk mempelajari akivitas antioksidan dari ekstrak metanol daun Soyogik (Saurauia Bracteosa DC.). Daun Soyogik diekstraksi dengan metode maserasi menggunakan pelarut metanol. Ekstrak pekat kemudian dilakukan pengujian aktivitas antioksidan dengan metode DPPH. Hasil penelitian menunjukkan bahwa ekstrak metanol daun Soyogik memiliki nilai $\mathrm{IC}_{50}$ sebesar $0,16 \mathrm{ppm}$.
\end{abstract}

Kata Kunci: Saurauia Bracteosa DC., Ekstrak Metanol, Antioksidan, Nilai $\mathrm{IC}_{50}$.

\section{ANTIOXIDANT ACTIVITY OF METHANOL EXTRACT FROM SOYOGIK (Saurauia Bracteosa DC.) LEAVES}

\begin{abstract}
This research aims to study on the antioxidant activity of methanol extract from Soyogik (Saurauia Bracteosa DC.) leaves. Soyogik leaves extracted by maceration method using methanol. Concentrated extract then testing the antioxidant activity by DPPH method. The results showed that the methanol extract of leaves Soyogik have $\mathrm{IC}_{50}$ value of $0.16 \mathrm{ppm}$.
\end{abstract}

Keywords: Saurauia Bracteosa DC., methanol extract, Antioxidant, $\mathrm{IC}_{50}$ value.

\section{PENDAHULUAN}

Radikal bebas merupakan molekul yang kehilangan elektron, sehingga molekul tersebut menjadi tidak stabil dan selalu berusaha mengambil elektron dari molekul atau sel lain. Untuk mencapai kestabilan molekul, radikal bebas akan bereaksi dengan molekul disekitarnya untuk memperoleh pasangan elektron disekelilingnya. Dampak reaktivitas senyawa radikal bebas dapat menyebabkan kerusakan sel atau jaringan, penyakit autoimun, penyakit degeneratif, hingga kanker (Sadikin, 2001). Oleh karena itu, tubuh memerlukan substansi penting, yakni antioksidan yang dapat membantu melindungi tubuh dari serangan radikal bebas.

Antioksidan merupakan senyawa atau molekul yang dapat mencegah terjadinya proses oksidasi yang disebabkan oleh radikal bebas. Antioksidan dikelompokan dalam bentuk yaitu: sintetik dan alami. Sekarang ini, antioksidan sintetik dibatasi penggunaannya akibat adanya kekhawatiran terhadap efek samping yang mungkin dapat terjadi (Winarsi, 2007). Kekurangan antioksidan sintetik menjadikan antioksidan alami sebagai pilihan utama dalam menangkal radikal bebas.

Salah satu tumbuhan yang berpotensi sebagai sumber antioksidan adalah Soyogik. Soyogik (Saurauia bracteosa DC) adalah tanaman dalam Famili Actinidiaceae yang merupakan endemik Indonesia, kebanyakan tanaman ini tersebar di Pulau Jawa dan Bali. Kadji et al., (2013) menyatakan daun Soyogik memiliki aktivitas antioksidan yang sangat kuat. Nilai $\mathrm{IC}_{50}$ dari ekstrak maserasi dengan etanol 70\% sebesar 38,01 ppm. Hasil ini didukung dengan kandungan senyawa yang terdapat dalam daun Soyogik yaitu: senyawa fenolik, steroid, flavonoid, dan saponin. Pada penelitian kali ini, peneliti ingin meneliti ekstrak daun Soyogik dengan menggunakan pelarut yang lain. Oleh karena itu, peneliti tertarik meneliti lebih lanjut mengenai aktivitas antioksidan pada daun Soyogik. 


\section{METODOLOGI PENELITIAN}

\section{Waktu dan Tempat Penelitian}

\begin{abstract}
Penelitian ini dilakukan di Laboratorium Kimia Organik dan Laboratorium Biokimia Fakultas Matematika dan Ilmu Pengetahuan Alam Universitas Sam Ratulangi, Manado, serta di Laboratorium Penelitian Kimia Universitas Padjajaran, Bandung, selama empat bulan dari bulan Agustus sampai November tahun 2016.
\end{abstract}

\section{Alat}

Peralatan yang digunakan dalam penelitian ini adalah oven, neraca analitik, Alumunium foil, alat penggiling, ayakan 65 mesh, desikator, labu pemisah, pemanas, satu set stirrer, satu set alat vacum rotary evaporator, mikropipet Eppendorff Research $1000 \mu \mathrm{L}$, alat-alat gelas pyrex, dan spektrofotometer UV-Vis (Shimadzu 1800 series).

\section{Bahan}

Bahan yang digunakan dalam penelitian ini adalah daun Soyogik yang diperoleh dari Desa Silian, Kecamatan Silian Raya, Kabupaten Minahasa Tenggara.

Bahan kimia yang digunakan dalam peneitian ini adalah kertas saring, akuades, dan bahan kimia berkualifikasi teknis yang didestilasi kembali, seperti: metanol, serta bahan kimia lainnya seperti: 1,1-difenil-2pikrihidrazil (DPPH).

\section{Peparasi Sampel}

Sampel dikeringkan selama 1 minggu. Setelah itu, dimasukkan ke dalam oven bersuhu $40^{\circ} \mathrm{C}$ hingga benar-benar kering. Setelah dikeringkan sampel diblender hingga berbentuk serbuk lalu diayak dengan ayakan 65 mesh.

\section{Uji Kadar Air}

Wadah kosong sebagai media sampel ditimbang dan dicatat beratnya sebagai A. Kemudian sampel yang telah dipreparasi ditimbang sebanyak 2 gram (B), dan dipanaskan dalam oven dengan temperature pemanasan $105^{\circ} \mathrm{C}$ selama tiga jam. Setelah tiga jam, sampel dimasukkan ke dalam desikator selama 30 menit. Kemudian, berat akhir sampel wadah ditimbang dan dicatat beratnya sebagai $C$. Perhitungan kadar air menggunakan rumus sebagai berikut:

$$
\text { Kadar air }=\frac{(A+B)-C}{B} \times 100 \%
$$

Keterangan:

$\mathrm{A}=$ Berat wadah

$\mathrm{B}=$ Berat sampel sebelum dipanaskan

$\mathrm{C}=$ Berat sampel + wadah setelah dipanaskan

\section{Ekstraksi}

Sebanyak 4 kg serbuk Soyogik dimasukkan ke dalam wadah, kemudian dimaserasi dengan pelarut metanol selama $3 \times 24$ jam. Setelah itu, sampel disaring dan filtrat yang diperoleh ditampung. Sementara itu, residu hasil penyaringan diekstraksi lagi sebanyak dua kali seperti cara sebelumnya. Filtrat yang diperoleh dievaporasi menggunakan rotary evaporator pada suhu $40^{\circ} \mathrm{C}$ sampai diperoleh ekstrak pekat.

\section{Uji Aktivitas Antioksidan}

Larutan sampel dan DPPH dibuat terlebih dahulu. Ekstrak sampel dilarutkan dalam metanol dengan konsentrasi $5 \mathrm{mg}$ ekstrak $/ 50 \mathrm{~mL}$ metanol $(100 \mu \mathrm{g} / \mathrm{mL})$ dan larutan DPPH dibuat konsentrasi $0,4 \mathrm{mM}$ (4 mg DPPH/ $25 \mathrm{~mL}$ metanol). Larutan sampel yang telah dibuat diencerkan dengan berbagai variasi konsentrasi dengan total volume $5 \mathrm{~mL}$ dan dimasukkan ke dalam tabung reaksi sebagai larutan uji dan dibuat juga untuk blanko. Selanjutnya, ke dalam tabung reaksi larutan uji ditambahkan $1 \mathrm{~mL}$ larutan DPPH dengan selang waktu penambahan 30 detik dan diinkubasi selama 30 menit dalam kondisi gelap. Setelah 30 menit, blanko dan larutan uji diukur absorbansinya dengan menggunakan spektrofotometer UV-Vis pada panjang gelombang $517 \mathrm{~nm}$. Nilai absorbansi dari setiap variasi konsentrasi dicatat dan dihitung $\%$ inhibisi dan nilai $\mathrm{IC}_{50}$. Pengujian dilakukan sebanyak dua kali. Perhitungan nilai $\mathrm{IC}_{50}$ dinyatakan dengan persamaan regresi linear dan perhitungan $\%$ inhibisi menggunakan rumus sebagai berikut:

$$
\% \text { Inhibisi }=\frac{\text { Akontrol }- \text { Asampel }}{\text { Akontrol }} \times 100 \%
$$


Keterangan:

$\mathrm{A}_{\text {kontrol }}=$ Absorbansi DPPH

$\mathrm{A}_{\text {sampel }}=$ Absorbansi DPPH + sampel

\section{HASIL DAN PEMBAHASAN}

\section{Uji Kadar Air}

Pengujian kadar air, bertujuan untuk menentukan kadar air dari sampel.

Kandungan kadar air dari sampel yang baik yaitu dibawah $10 \%$, karena akan tahan lama dalam penyimpanan. Apabila sampel memiliki kadar air yang besar, ditakutkan sampel akan menghasilkan mikroorganisme yang dapat mengubah konformasi senyawa kimia yang terkandung pada sampel tersebut. Pengujian kadar air pada daun soyogik dilakukan tiga kali pengulangan, dengan hasil yang ditunjukkan pada Tabel 1.

Tabel 1. Kadar Air Daun Soyogik

\begin{tabular}{c|c}
\hline Pengujian ke- & Kadar Air (\%) \\
\hline I & 7,83 \\
\hline II & 7,68 \\
\hline III & 7,57 \\
\hline Rata-rata & $\mathbf{7 , 6 9}$ \\
\hline
\end{tabular}

Dari tabel 1 diperoleh hasil yang menunjukkan bahwa kadar air pada daun soyogik memiliki rata-rata $7,69 \%$.

\section{Ekstraksi Daun Soyogik}

Serbuk kering daun soyogik sebanyak $4 \mathrm{~kg}$ yang telah disaring dengan ayakan 65 mesh dimaserasi dengan menggunakan pelarut metanol sebanyak 20 L secara berulang-ulang, yaitu $3 \times 24$ jam. Pengulangan yang dilakukan ini bertujuan untuk mengoptimalisasi proses ektraksi maserasi dalam mengikat senyawa yang terkadung dalam sampel. Dalam pengulangan proses ini dilihat apakah pelarut metanol tidak lagi berwarna jika dicampurkan dengan sampel, maka senyawa dalam sampel telah terlarut dalam pelarut. Metode ekstraksi maserasi dipilih karena metode ini tidak menggunakan pemanasan dalam prosesnya sehingga mencegah terjadinya kerusakan pada senyawa yang tidak tahan panas dan dikarenakan belum diketahuinya karakter senyawa. Dalam penggunaan metanol sebagai pelarut dikarenakan pelarut ini dapat melarutkan senyawa polar maupun non-polar sehingga sangat baik mengekstrak senyawa metabolit sekunder yang terkandung pada sampel yang digunakan (Cordell, 1981).

\section{Aktivitas Antioksidan}

Pengujian aktivitas antioksidan dilakukan untuk mengetahui nilai $\mathrm{IC}_{50}$ dari sampel.IC I0 $_{50}$ adalah konsentrasi penghambatan antioksidan setengah maksimal pada radikal bebas. Pengujian dilakukan terhadap ekstrak metanol sampel dan fraksi-fraksi hasil partisi. Pada pengukuran antioksidan ekstrak methanol di didapatkan hasil seperti pada gambar 1 .

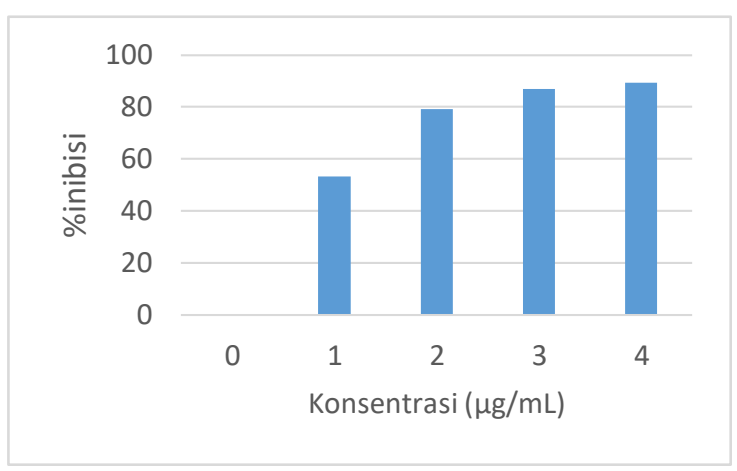

Gambar 1. Aktivitas Antioksidan Ekstrak metanol Daun Soyogik

Gambar 1 menunjukkan \% inhibisi meningkat seiring dengan peningkatan konsentrasi. Untuk melihat nilai $\mathrm{IC}_{50}$ esktrak metanol dibuat persamaan regresi seperti pada gambar 2 .

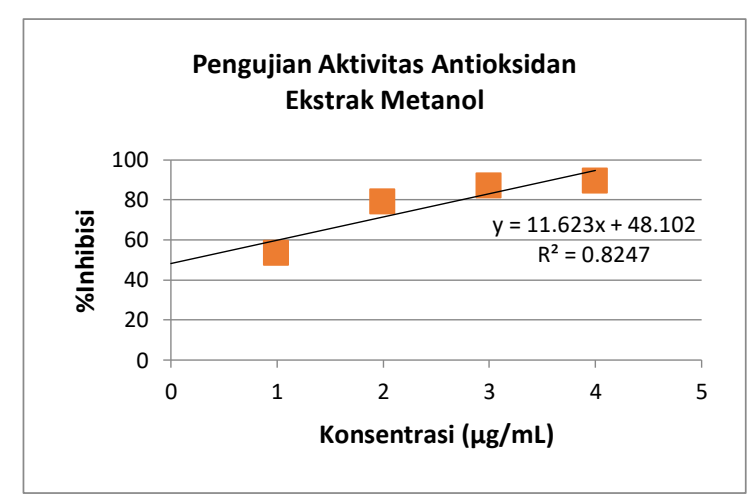

Gambar 2. Kurva Persamaan Regresi Linier Ekstrak Metanol Daun Soyogik 
Dari hasil yang diperoleh, pengujian aktivitas antioksidan ekstrak metanol memiliki aktivitas antioksidan yang baik dengan nilai $\mathrm{IC}_{50}$ sebesar $0,16 \mu \mathrm{g} / \mathrm{mL}$. Pehitungan nila $\mathrm{IC}_{50}$ dihitung menggunakan rumus persamaan regersi. Dari nilai $\mathrm{IC}_{50}$ yang diperoleh ekstrak metanol mempunyai aktivitas antioksidan yang sangat baik. Pernyataan ini didukung oleh BrandWilliam (1995) yang menyatakan zat yang mempunyai aktivitas antioksidan tinggi, akan mempunyai nilai $\mathrm{IC}_{50}$ yang tinggi.

Hasil perhitungan nilai $\mathrm{IC}_{50}$ ekstrak metanol ini juga lebih baik dibandingkan dengan nilai $\mathrm{IC}_{50}$ yang diperoleh menggunakan pelarut etanol $70 \%$ sebesar 38,01 ppm pada penelitian yang dilakukan oleh Kadji (2013).

Hasil nilai $\mathrm{IC}_{50}$ ekstrak metanol yang tinggi didukung dengan penelitian yang dilakukan oleh Maukar et al., (2013) menyatakan kandungan fenolik, flavonoid dan tanin ekstrak metanol berturut-turut adalah $43,06 \mathrm{mg} / \mathrm{kg}, 6,52 \mathrm{mg} / \mathrm{kg}$ dan 17,91 $\mathrm{mg} / \mathrm{kg}$.

Berdasarkan hasil kandungan fenolik yang diperoleh, diduga bila kandungan senyawa fenolik didalam sampel tinggi aktivitas antioksidannya juga akan tinggi. Hal ini didukung oleh Sudjadi dan Rohman dalam Ukieyanna (2012) yang mengungkapkan adanya inti aromatis pada senyawa fenolik dapat mereduksi fosfomolibdat fosfotungstat menjadi molibdenum yang ditandai dengan terbentuknya warna biru. Hasil kandungan flavonoid berbanding terbalik dengan hasil kandungan fenolik. Hasil ini menunjukkan bahwa kandungan fenolik dari setiap ekstrak tidak selalu bersumber pada golongan senyawanya. Ukieyanna (2012) menyatakan beberapa senyawa metabolit sekunder maupun metabolit primer yang dihasilkan oleh tumbuhan dapat menjadi senyawa antioksidan ataupun senyawa pengganggu aktivitas antioksidan. Pada hasil kandungan tanin menunjukan bahwa hasil yang diperoleh memiliki nilai yang kecil, hal ini disebabkan pelarut yang digunakan bersifat pelarut polar yaitu metanol sedangkan senyawa tanin termasuk dalam golongan polifenol yang pada umumnya larut pada pelarut non-polar.

\section{KESIMPULAN}

Ekstrak metanol memiliki nilai $\mathrm{IC}_{50}$ 0,16 ppm. Hasil nilai $\mathrm{IC}_{50}$ ini didukung hasil penelitian yang dilakukan oleh Maukar (2013) yang menyatakan bahwa kandungan flavonoid, fenolik, dan tanin ekstrak metanol berturut-turut adalah $43,06 \mathrm{mg} / \mathrm{kg}$, $6,52 \mathrm{mg} / \mathrm{kg}$ dan $17,91 \mathrm{mg} / \mathrm{kg}$.

\section{DAFTAR PUSTAKA}

Andarwulan, N., H. Wijaya., dan D. T. Cahyono.1996.Aktivitas Antioksidan dari Daun Sirih (Piper betle L.). Teknologi dan Industri Pangan. 7: 29-30.

Apak, R., K. Guclu , B. Demirata., M. Ozyurek, S. E. Celik., B. Bektasoglu., K. I. Beker., and D. Ozyurt. 2007. Comparative Evaluation of Various Total Antioxidant Capacity Assays Applied to Phenolic Compounds with CUPRAC Assay. Molecules. 12: 1496-1547.

Basset, J., R.C. Denny., G. H. Jeffrey., dan J. Mendham. 1994. Buku Ajar Vogel: Kimia Analisis Kuantitatif Anorganik. Edisi keempat. Terjemahan A. Handayana P. dan L. Setyono. Buku Kedokteran EGC, Jakarta.

Brand-William, W., M. E. Cuvelier., and C. Berset. 1995. Use of a Free Radical Method to Evaluated Antioxidant Activity. Lebensmittel-wissenchaft und Technologie. 28: 25-30.

Cordell, A. F. 1981. Introduction to Alkaloids. John Wiley And Sons Inc, New York.

Day, R. A., dan A. L. Underwood. 2002. Analisis Kimia Kuantitatif. Edisi keenam. Terjemahan Iis Sopyan. Erlangga, Jakarta.

Fessenden, R. J., dan J. S. Fessenden. 1986a. Kimia Organik. Edisi ketiga. Jilid 1. Terjemahan A. Handayana P. Erlangga, Jakarta.

Fessenden, R. J., dan J. S. Fessenden. 1986b. Kimia Organik. Edisi ketiga. Jilid 2. Terjemahan A. Handayana P. Erlangga, Jakarta. 
Handa, S. S., S. P. S. Khanuja., G. Longo., and D. D. Rakesh. 2008 Technologies for Medichal and Aromatic Plants. United Nations Industrial Development Organization and the International Centre for Science and High Technology. 5: 2154.

Harborne, J.B. 1996. Metode Fitokimia. Terbitan Kedua. Terjemahan Kokasih Padmawinata dan Iwang Soediro. ITB, Bandung.

Jadhav. S. S., A. D. Nimbalkar., Kulkarni., and D. L. Mandhavi. 1996. Food Antioxidants: Technological, Toxological, and Health Perspective. Edition D. L. Mandhavi, S. S. Deshpande and D. K. Salunkhe. Marcel Dekker, New York.

Kadji M. H., M. R.J. Runtuwene., dan G. Citraningtyas. 2013. Uji Fitokimia dan Aktivitas Antioksidan dari Ekstrak Etanol Daun Soyogik (Saurauia bracteosa DC). Jurnal Pharmacon. 3: 13-17.

Karyadi, E. 1997. Antioksidan: Resep Awet Mudat dan Umur Panjang From Uji Aktivitas Antiradikal Dengan Metode DPPH dan Penetapan Kadar Fenol Total Ekstrak Daun Keladi Tikus (Thyponium divaricatum (Linn) Decne). Pharmacon. 6: 51-56.

Maukar M. A., M. R. J. Runtuwene., dan J. Pontoh. 2013. Analisis Kandungan Fitokimia Dari Uji Toksisitas Ekstrak Metanol Daun Soyogik (Sauraula Bracteosa Dc) Dengan Menggunakan Metode Maserasi. Jurnal Ilmiah Sains. 13: 98-101.

Mojo, T., J. Abidjulu., dan M. R. J. Runtwene. 2016. Kajian Toksisitas Dari Fraksi Heksana, Etil Asetat dan Etanol Daun Soyogik (Saurauia bracteosa DC). Jurnal Mipa Unsrat Online. 5: 40-43.

Mokoginta, E. P., M. R. J. Runtuwene., dan F. Wehantouw. 2013. Pengaruh Metode Ekstraksi Terhadap Aktivitas Penangkal Radikal Bebas Ekstraak Metanol Kulit Biji Pinang Yaki (Areca Vestiaria Giseke). Pharmacon. 2: 109-113.
Prayoga G. 2013. Fraksinasi, Uji Aktivitas Antioksidan dengan Metode DPPH dan Identifikasi Golongan Senyawa Kimia dari Ekstrak Teraktif Daun Sambang Darah (Excoecaria cochinchinensis Lour). Pharmacon. 5: 41-48.

Sadikin, M. 2001. Pelacakan Dampak Radikal Bebas terhadap Makromolekul. Kumpulan Makalah Pelatihan: Radikal Bebas dan Antioksidan dalam Kesehatan. Fakultas Kedokteran UI. Jakarta.

Silalahi, R. M. 2010. Karakterisasi Simplisia, Skrining Fitokimia Dan Uji Aktivitas Antioksidan Ekstrak Etanol Daun Fraksi Bunga Tumbuhan Brokoli (Brassicaoleracea L. var. botrytis L.). [skripsi]. Fakultas Farmasi Universitas Sumatera Utara, Medan.

Suryanto, E. 2012. Fitokimia Antioksidan. Putra Media Nusantara, Surabaya.

Tamat, S. R., T. Wikanta., dan L. S. Maulina. 2007. Aktivitas Antioksidan dan Toksisitas Senyawa Bioaktif dari Ekstrak Rumput Laut Hijau Ulva reticulata Forsskal. Jurnal Ilmu Kefarmasian Indonesia. 5: 31-36.

Ukieyanna, E. 2012. Aktivitas Antioksidan, Kadar Fenolik, dan Flavonoid Total Tumbuhan Suruhan (Peperomia Pellucida L. Kunth) [skripsi]. FMIPA Institut Pertanian, Bogor.

Wungkana, I., E. Suryanto., dan L. Momuat. 2013. Aktivitas Antioksidan dan Tabir Surya Fraksi Fenolik dari Limbah Tongkol Jagung (Zea mays L.). Pharmacon. 2: 149-155.

Zuhra, C. F., J. B. Tarigan., dan H. Sitohang. 2008. Aktivitas Antioksidan Senyawa Flavonoid dari Daun Katuk (Saurapus androgunus (L) Merr.). Jurnal Biologi Sumatera. 3:7-10. 